\title{
Analisis Pemungutan Pajak Daerah di Kabupaten Bolaang Mongondow
}

\author{
SAMSUL MOKODOMPIT ${ }^{1}$, GRACE B. NANGOI ${ }^{2}$, VENTJE ILAT ${ }^{3}$ \\ 1,2,3 Program Magister Akuntansi, Fakultas Ekonomi dan Bisnis Universitas Sam Ratulangi \\ email:samsulmokodompit@yahoo.com ${ }^{1}$, gracebn@yahoo.com², ventje_ilat@unsrat.ac.id ${ }^{3}$
}

\begin{abstract}
Local tax is a compulsory contribution to an area owed by an individual or a coercive body under the Act by not obtaining direct remuneration and being used for regional purposes for the greatest possible prosperity of the people. Collection is a series of activities ranging from the collection of data objects and tax subjects, determination of the amount of tax payable until tax collection activities to the taxpayer and supervision of its payment. The purpose of this study is to analyze the implementation of local tax collection in Bolaang Mongondow regency and analyze the obstacles and efforts undertaken. This research uses qualitative method with exploratory approach. Local Government Finance Agency of Bolaang Mongondow is the object of this research. Data were obtained by in-depth interviews and documentation study. Key informants were determined purposively to obtain the accurate information. Semi structured in-depth interviews were conducted to collect data. Validity or credibility of the data was gained by triangulation. Data were analysed by using Miles and Huberman model which consists of data reduction, display data and drawing conclusion. The results show that the implementation of local tax collection is in accordance with Government Regulation No. 55 of 2016 consists of 1) types of taxes and tax setting arrangements in local regulations 2) taxpayer registration and tax period 3) determination, payment and tax reporting 4) billing and write-off of tax receivables 5) objections and appeals. While the constraints encountered in the collection process consist of human resources, budget and facilities and awareness of taxpayers. Efforts made are in the form to improve the human resources, the budget and facilitation, leadership and socialization
\end{abstract}

\section{Keywords: Local Tax Collection, Human Resources, Budget and Facilities, Awareness of Taxpayer.}

\begin{abstract}
Abstrak. Pajak daerah adalah kontribusi wajib kepada daerah yang terutang oleh orang pribadi atau badan yang bersifat memaksa berdasarkan Undang-Undang dengan tidak mendapatkan imbalan secara langsung dan digunakan untuk keperluan daerah bagi sebesar-besarnya kemakmuran rakyat. Pemungutan adalah suatu rangkaian kegiatan mulai dari penghimpunan data objek dan subjek pajak, penentuan besarnya pajak yang terutang sampai kegiatan penagihan pajak kepada wajib pajak serta pengawasan penyetorannya. Tujuan penelitian ini untuk menganalisis pelaksanaan pemungutan pajak daerah di Kabupaten BolaangMongondow, kendala yang menjadi penghambat dan upaya-upaya yang dilakukan. Penelitian ini menggunakan metode kualitatif dengan pendekatan eksploratori. Pemerintah Kabupaten Bolaang Mongondow Badan Keuangan Daerah sebagai objek penelitian. Data diperoleh melalui teknik wawancara mendalam dan studi dokumentasi. Informan kunci ditentukan secara purposive untuk mendapatkan hasil informasi yang tepat dan akurat. Wawancara menggunakan In-depth interview semi terstruktur. Metode triangulasi sumber digunakan dalam pengujian validitas atau kredibilitas data. Teknik analisis yang digunakan yaitu model Miles and Huberman yang terdiri dari data reduction, data display dan drawing conclusion. Hasil penelitian menunjukkan bahwa pelaksanaan pemungutan pajak daerah sudah sesuai dengan PP No 55 Tahun 2016 yang terdiri dari 1) jenis-jenis pajak dan pengaturan penetapan pajak dalam peraturan daerah; 2) pendaftaran wajib pajak dan masa pajak; 3) penetapan, pembayaran dan pelaporan pajak; 4) penagihan dan penghapusan piutang pajak; 5) keberatan dan banding. Kendala yang ditemui dalam proses pemungutan terdiri dari sumber daya manusia, anggaran dan fasilitas serta kesadaran wajib pajak. Upaya yang dilakukan yaitu dalam bentuk perbaikan sumber daya manusia, anggaran dan fasilitis, kepemimpinan dan sosialisasi.
\end{abstract}

Kata Kunci : Pemungutan Pajak Daerah, Sumber Daya Manusia, Anggaran dan Fasilitas, Kesadaran Wajib Pajak.

\section{Pendahuluan}

Undang-Undang Nomor 33 Tahun 2004 tentang Perimbangan Keuangan antara Pemerintah Pusat dan Pemerintah Daerah, diuraikan bahwa Negara Kesatuan Republik Indonesia menyelenggarakan pemerintahan negara dan pembangunan nasional untuk mencapai masyarakat adil, makmur, dan merata berdasarkan Pancasila dan Undang-Undang Dasar RI Tahun 1945. Dalam rangka penyelenggaraan pemerintahan dan melaksanakan pembangunan, Negara Kesatuan Republik 
Indonesia dibagi atas daerah-daerah provinsi dan daerah provinsi tersebut terdiri atas daerah-daerah kabupaten dan kota. Tiap-tiap daerah mempunyai hak dan kewajiban untuk mengatur dan mengurus sendiri urusan pemerintahannya untuk meningkatkan efisiensi dan efektifitas penyelenggaraan pemerintahan dan pelayanan kepada masyarakat. Penyelenggaraan pemerintahan yang menjadi kewenangan daerah dibiayai dari APBD, sedangkan penyelenggaraan kewenangan pemerintahan yang menjadi tanggung jawab pemerintah dibiayai dari APBN. Untuk melaksanakan pembangunan dan penyelenggaraan urusan pemerintahan di daerah, sumber dana memegang peranan penting dalam mewujudkan keberhasilan pembangunan dan pemerintahan. Salah satu sumber dana yang cukup berperan penting bagi kelangsungan pelaksanaan pembangunan dan penyelenggaran urusan pemerintahan adalah penerimaan dari pendapatan asli daerah yang salah satunya berasal dari pajak daerah.

Pajak daerah yang selanjutnya disebut pajak, menurut Peraturan Pemerintah No. 55 Tahun 2016 adalah kontribusi wajib kepada daerah yang terutang oleh orang pribadi atau badan yang bersifat memaksa berdasarkan Undang-Undang dengan tidak mendapatkan imbalan secara langsung dan digunakan untuk keperluan daerah bagi sebesar-besarnya kemakmuran rakyat. Sesuai dengan UndangUndang Nomor 28 Tahun 2009 tentang pajak daerah dan retribusi daerah, jenis pajak daerah terbagi menjadi dua yaitu pajak provinsi dan pajak kabupaten/kota. Pajak provinsi terdiri dari pajak kendaraan bermotor, bea balik nama kendaraan bermotor, pajak air permukaan serta pajak rokok. Sedangkan pajak kabupaten/kota terdiri dari pajak hotel, pajak restoran, pajak hiburan, pajak reklame, pajak penerangan jalan, pajak parkir, pajak mineral bukan logam dan batuan, pajak air tanah, pajak sarang burung walet, pajak bumi dan bangunan perdesaan dan perkotaan serta bea perolehan hak atas tanah dan bangunan.

Dengan berlakunya Undang-Undang Nomor 28 Tahun 2009 tentang pajak daerah dan retribusi daerah, maka pemerintah daerah memperoleh perluasan objek pajak daerah sebagai sumber penghasilan tambahan. Perluasan objek pajak daerah yang diatur dalam Undang-Undang tersebut meliputi perluasan basis pajak daerah yang telah ada, penambahan objek pajak baru dan pendaerahan objek pajak pusat menjadi pajak daerah. Latar belakang pembentukan Undang-Undang Nomor 28 Tahun 2009 tentang pajak daerah dan retribusi daerah antara lain untuk memberikan kewenangan yang lebih besar kepada daerah dalam mengatur pajak daerah dan retribusi daerah, sebagai dasar dalam meningkatkan akuntabilitas dalam penyediaan layanan dan pemerintahan, memperkuat otonomi daerah serta memberikan kepastian hukum bagi masyarakat dan dunia usaha.

Jenis pajak daerah yang dikelola pemerintah Kabupaten Bolaang Mongondow terbagi atas 2 kelompok yaitu pajak daerah yang dipungut berdasarkan penetapan kepala daerah dan jenis pajak yang dibayar sendiri berdasarkan penghitungan oleh wajib pajak. Untuk pajak daerah yang dipungut berdasarkan penetapan kepala daerah terdiri dari pajak reklame dan PBB-P2. Selanjutnya jenis pajak yang dibayar sendiri berdasarkan penghitungan oleh wajib pajak terdiri dari pajak restoran, pajak hiburan, pajak penerangan jalan, pajak mineral bukan logam dan batuan, dan BPHTB. Menurut PP No. 55 Tahun 2016, Pemungutan adalah suatu rangkaian kegiatan mulai dari penghimpunan data objek dan subjek pajak, penentuan besarnya pajak yang terutang sampai kegiatan penagihan pajak kepada wajib pajak serta pengawasan penyetorannya. Dalam pelaksanaannya, pemungutan pajak daerah tidak dapat diborongkan artinya seluruh proses kegiatan pemungutan pajak tidak dapat diserahkan kepada pihak ketiga, walaupun dimungkinkan adanya kerjasama dengan pihak ketiga dalam proses pemungutan pajak, antara lain pencetakan formulir perpajakan, pengiriman surat-surat kepada wajib pajak atau penghimpunan data objek dan subjek pajak. Kegiatan yang tidak dapat dikerjasamakan dengan pihak ketiga adalah kegiatan penghitungan besarnya pajak yang terutang, pengawasan penyetoran pajak dan penagihan pajak.

Pelaksanaan pemungutan pajak daerah di Kabupaten Bolaang Mongondow dijalankan berdasarkan Peraturan Pemerintah No. 55 Tahun 2016 dan Peraturan Daerah No.1-7 Tahun 2011. Adapun realisasi penerimaan pajak daerah di Kabupaten Bolaang Mongondow untuk lima tahun terakhir, dari tahun 2012 sampai tahun 2016 setiap tahunnya presentasi penerimaan pajak daerah mengalami fluktuatif, dimana tahun 2013 mengalami kenaikan sebesar 156.56 persen dari tahun 2012 dengan presentasi 141.76 persen, sementara posisi untuk tahun 2014 presentasi penerimaan pajak daerah turun dengan presentasi penerimaan pajak 120.72, selanjutnya tahun 2015 penerimaan pajak daerah kembali naik sebesar 145.09 persen dan tahun 2016, presentasi penerimaan pajak daerah kembali turun dengan presentasi 122,78 persen.

Pemerintah Daerah Kabupaten Bolaang Mongondow yang mempunyai luas wilayah terbesar dengan memiliki luas sebesar 5.397,89 $\mathrm{m} 2$ dengan presentasi 53 persen dari luas provinsi Sulawesi 
Utara, dengan luasnya wilayah serta didukung sumber daya alam yang ada, sangatlah berpotensi bila sumber daya yang ada digali secara maksimal guna meningkatkan penerimaan pajak daerah. Berdasarkan keadaan dan fenomena diatas, guna lebih meningkatkan Pendapatan Asli Daerah (PAD) terutama dalam hal pajak daerah sebagai salah satu sumber pembiayaan daerah maka, pentingnya pemerintah daerah untuk melakukan analisis atas pelaksanaan pemungutan pajak daerah untuk peningkatan penerimaan daerah dalam pelaksanaan pembangunan daerah.

Tujuan penelitian ini untuk : 1) menganalisis pelaksanaan pemungutan pajak daerah di Kabupaten Bolaang Mongondow 2) menganalisis kendala 3) menganalisis upaya dalam mengatasi kendala pemungutan pajak daerah dalam peningkatan penerimaan asli daerah.

\section{Model Analisis}

Model analisis dalam penelitian ini dapat digambarkan sebagai berikut:

Gambar 3.1

Model Analisis Penelitian

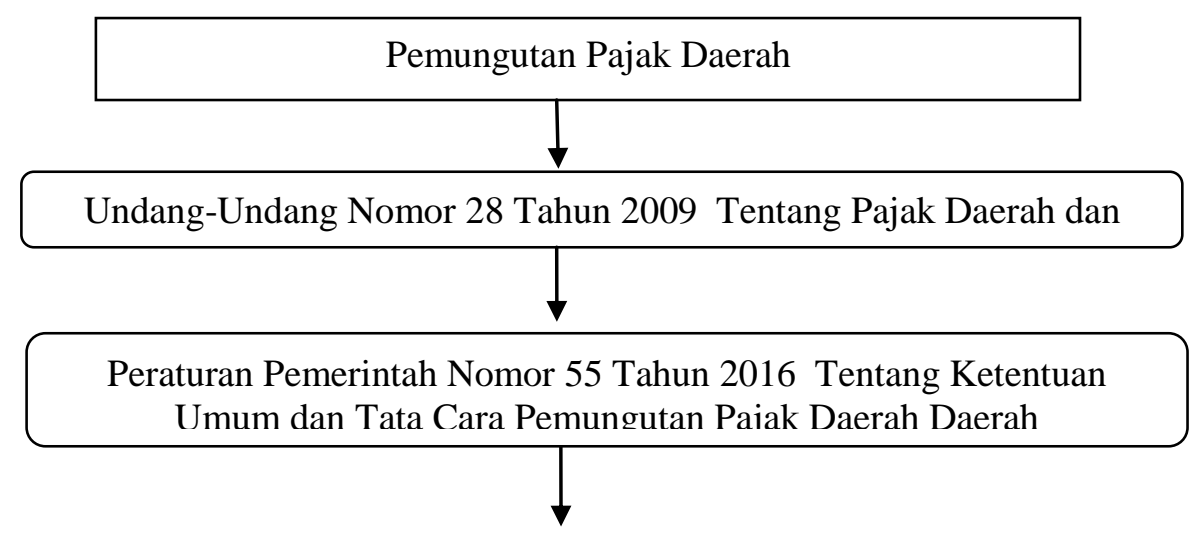

Peraturan Daerah Nomor 01,02,03,04,05,06 dan 06 Tahun 2011 tenang Jenis-Jenis Pajak Daerah di Kabupaten Bolaang Mongondow

Pertanyaan Riset :

1. Bagaimana pemungutan pajak daerah di Pemerintah Kabupaten Bolaang Mongondow?

2. Adakah Kendala/kesulitan yang ditemui dalam pelaksanaan pemungutan pajak daerah di Kabupaten Bolaang Mongondow?

3. Apa upaya yang dilakukan untuk mengatasi kendala/kesulitan dalam pelaksanaan pemungutan pajak daerah di Kabupaten Bolaang Mongondow?

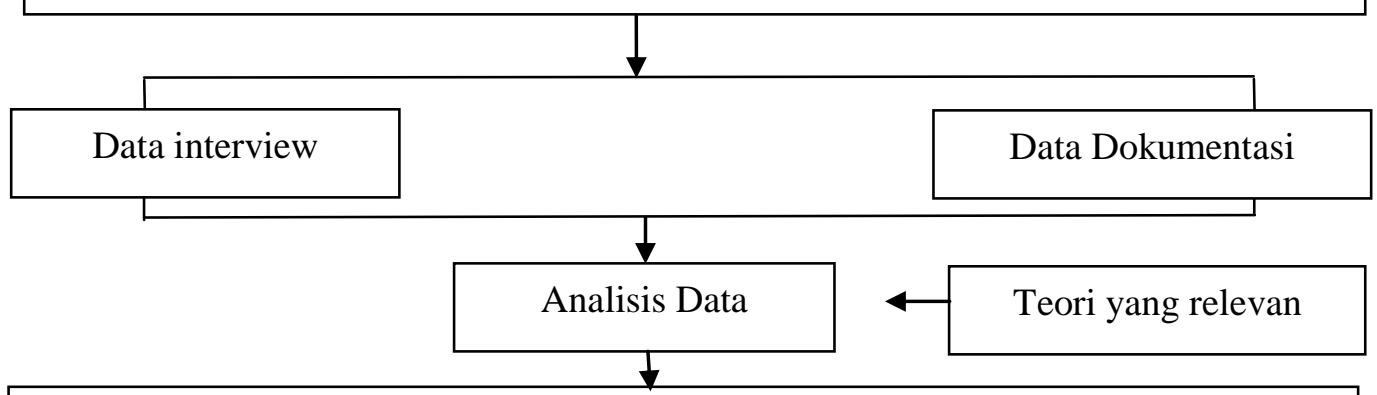

Proposisi Hasil Penelitian : analisis pelaksanaan pemungutan pajak daerah untuk memaksimalkan pemungutan pajak harus didukung dengan kesadaran wajib pajak serta dukungan berupa anggaran dan fasilitas yang memadai.

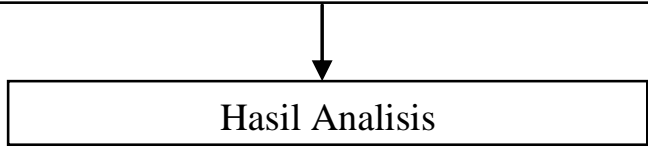




\section{Metode Penelitian}

Penelitian ini menggunakan metode penelitian kualitatif dengan pendekatan eksploratori (exploratory approach). Sugiyono (2015:1) menjelaskan bahwa metode penelitian kualitatif adalah metode penelitian yang digunakan untuk meneliti pada kondisi obyek yang alamiah (sebagai lawannya adalah eksprimen) dimana peneliti adalah sebagai intrumen kunci. Menurut Amirin (2009), penelitian eksploratif merupakan salah satu pendekatan penelitian yang digunakan untuk meneliti sesuatu (yang menarik perhatian) yang belum diketahui, belum dipahami, belum dikenali dengan baik. Pendapat lain, menurut Ibrahim (2015:61) pendekatan eksploratori dalam penelitian kualitatif adalah cara kerja penelitian yang dimaksud untuk menemukan lebih jauh dan mendalam terhadap kemungkinankemungkinan lain dari permasalahan yang diteliti. Dengan kata lain pendekatan eksploratori, tidak lagi sekedar menggambarkan atau melukiskan/menjelaskan seperti apa adanya realitas yang dikaji sebagaimana pada metode deskriptif, namun juga tidak melalui tahapan uji coba sebagaimana pada metode eksperimen.

Teknik pengumpulan data yang dilakukan dalam penelitian ini adalah wawancara dan studi dokumentasi. Penentuan infoman dilakukan dengan metode purposive sampling yaitu teknik pengambilan sampel dengan pertimbangan tertentu. Menurut Sugiyono (2012:216), purposive sampling yaitu menetapkan kriteria tertentu yang harus dipenuhi oleh informan yang akan dijadikan sumber informasi. Metode analisis data yang digunakan dalam penelitian ini adalah analisis model Milles dan Huberman. Aktivitas analisis data Milles and Huberman dalam Sugiyono (2015:91) terdiri dari data reduction, data display dan conclusion drawing/verification yang dilakukan secara interaktif dan berlangsung secara terus menerus sampai tuntas, sehingga datanya mencapai jenuh. Uji keabsahan data dalam penelitian ini menggunakan uji credibility yang terdiri dari triangulasi sumber, triangulasi teknik dan member checking. Uji dependability dilakukan oleh dosen pembimbing untuk memeriksa transkrip hasil wawancara, bagaimana melakukan analisis data, melakukan keabsahan data penelitian sampai membuat kesimpulan.

\section{Analisis dan Pembahasan}

Penelitian ini dilakukan selama 2 (dua) bulan sejak bulan Agustus sampai Oktober 2017 dengan melakukan wawancara sesuai dengan pedoman wawancara kepada informan dengan menggunakan alat perekam untuk merekam isi wawancara serta menggunakan instrumen pendukung lainnya berupa buku catatan, kamera untuk mendokumentasikan kegiatan di lapangan dan laptop untuk mengetik hasil penelitian dan rekaman wawancara sehingga terbentuk transkrip.

\section{Pelaksanaan Pemungutan Pajak Daerah di Kabupaten Bolaang Mongondow}

Pemungutan pajak menurut Peraturan Pemerintah No. 55 Tahun 2016 adalah suatu rangkaian kegiatan mulai dari penghimpunan data objek dan subjek pajak, penentuan besarnya pajak yang terutang sampai kegiatan penagihan pajak kepada wajib pajak serta pengawasan dan penyetorannya.

1. Regulasi. Yang menjadi landasan dalam pemungutan pajak daerah di Kabupaten Bolaang Mongondow yaitu Peraturan Pemerintah Nomor 55 Tahun 2016 tentang ketentuan umum dan tata cara pemungutan pajak daerah yang dituangkan dalam Perda. Adapun Perda dimaksud adalah Perda Nomor 01 Tahun 2011 tentang Pajak Penerangan Jalan, Perda Nomor 2 Tahun 2011 tentang Pajak Hiburan, Perda Nomor 03 Tahun 2011 tentang Pajak Reklame, Perda nomor 04 Tahun 2011 tentang Pajak Hotel dan Restoran, Perda Nomor 05 Tahun 2011 tentang Pajak Mineral bukan logam dan Batuan, Perda nomor 06 Tahun 2011 tentang Pajak Bumi dan Bangunan Perdesaan dan Perkotaan, dan Perda Nomor 07 Tahun 2011 tentang Pajak perolehan Hak Atas tanah dan Bangunan (BPHTB).

2. Jenis-jenis pajak daerah yang dipungut di Kabupaten Bolaang Mongondow terdiri dari 2 jenis yaitu pajak kabupaten yang dipungut berdasarkan penetapan kepala daerah dan jenis pajak kabupaten yang dibayar sendiri berdasarkan penghitungan oleh wajib pajak. Pemungutan berdasarkan penetapan kepala daerah terdiri atas pajak reklame dan PBB-P2. Selanjutnya kelompok jenis pajak daerah yang dibayar sendiri berdasarkan perhitungan oleh wajib pajak terdiri atas pajak hotel, pajak restoran, pajak hiburan, pajak penerangan jalan, pajak mineral bukan logam dan batuan serta BPHTB. Selanjutnya dalam peraturan daerah mengatur juga ketentuan mengenai 1) nama, objek pajak, dan subjek pajak; 2) dasar pengenaan, tarif dan cara penghitungan pajak; 3) wilayah pemungutan; 4) masa pajak; 5) penetapan; 6) tata cara pembayaran dan penagihan; 7) kedaluwarsa; 8) sanksi administratif dan 9) tanggal mulai berlakunya. 
3. Pendaftaran wajib pajak dan masa pajak. Pendaftaran wajib pajak untuk jenis pajak yang dipungut berdasarkan penetapan kepala daerah menggunakan surat pendaftaran objek pajak, Selanjutnya jenis pajak yang dibayar sendiri berdasarkan penghitungan oleh wajib pajak diwajibkan mendaftarkan diri kepada kepala daerah untuk mendapatkan nomor pokok wajib pajak daerah. Sedangkan masa pajak daerah untuk jenis pajak yang dibayar sendiri berdasarkan penghitungan wajib pajak telah sesuai dengan Peraturan Pemerintah No. 55 Tahun 2016 disertai dengan Peraturan Daerah untuk masing-masing jenis pajak daerah. Masa pajak berlaku untuk jenis pajak yang dibayar sendiri berdasarkan penghitungan oleh wajib pajak serta ketentuan masa pajak dikecualikan untuk BPHTB.

4. Penetapan, pembayaran, pelaporan dan ketetapan pajak. Proses penetapan pajak daerah telah dilaksanakan sesuai dengan Peraturan Pemerintah Nomor 55 Tahun 2016 yaitu dilakukan oleh kepala daerah atau pejabat yang ditunjuk. Selanjutnya proses pembayaran juga telah sesuai dengan ketentuan peraturan pemerintah dan peraturan daerah dimana dilaksanakan secara lebih aktif oleh pemungut pajak dengan cara menjemput setoran dari wajib pajak yang bersangkutan disamping menunggu wajib pajak melakukan penyetoran atau pembayaran pajak. Pelaporan pajak dilakukan secara rutin sesuai dengan peraturan pemerintah dan peraturan daerah yang menyajikan pembayaran atau penyetoran wajib pajak untuk jenis pajak yang dibayar sendiri berdasarkan penghitungan oleh wajib pajak dengan mengisi SPTPD yang paling sedikit memuat omzet dan jumlah pajak yang tertuang dalam satu masa pajak. Wajib pajak menyampaikan SPTPD yang dilampiri SSPD kepada kepala daerah atau pejabat yang ditunjuk untuk jenis pajak yang dibayar sendiri berdasarkan penghitungan wajib pajak. Proses pelaporan pajak dilakukan secara rutin dengan mengisi SPTPD yang paling sedikit memuat omzet dan jumlah pajak yang tertuang dalam satu masa pajak.

5. Penagihan dan penghapusan piutang pajak. Penagihan pajak dilakukan oleh Kepala Daerah dengan menerbitkan STPD untuk jenis pajak daerah yang dipungut berdasarkan penetapan Kepala Daerah dalam hal pajak terutang dalam SKPD atau SPPT, penagihan pajak dengan surat paksa dilaksanakan berdasarkan ketentuan peraturan perundang-undangan serta ketentuan mengenai pedoman penagihan diatur dengan Peraturan Menteri Keuangan dengan pertimbangan menteri yang menyelenggarakan urusan pemerintahan dalam negeri yang secara khusus sesuai dengan peraturan. Sedangkan penghapusan piutang pajak daerah di Kabupaten Bolaang Mongondow telah dilaksanakan sesuai dengan Peraturan Pemerintah No. 55 Tahun 2016 dan Peraturan Daerah yang ditetapkan oleh Pemerintah Daerah. Penghapusan piutang pajak dilakukan karena piutang pajak yang tidak mungkin ditagih lagi karena hak untuk melakukan penagihan sudah kadaluwarsa dapat dihapuskan.

6. Keberatan dan banding. Pengajuan keberatan oleh wajib pajak telah dilaksanakan sesuai dengan peraturan yang ditetapkan oleh pemerintah daerah baik Peraturan Pemerintah maupun Peraturan Daerah yang menjadi landasan dalam pelaksanaan pemungutan pajak daerah. Hal ini terlihat bahwa wajib pajak mengajukan surat keberatan kepada kepala daerah melalui kepala badan keuangan daerah atas pemungutan pajak yang tidak sesuai. Demikian juga proses banding telah sesuai dengan PP No. 55 Tahun 2016 dan Peraturan Daerah yang ditetapkan pemerintah dimana wajib pajak dapat mengajukan banding atas surat keputusan keberatan yang ditetapkan oleh kepala daerah paling lama 3 (tiga) bulan sejak keputusan diterima dengan dilampiri salinan surat keputusan keberatan tersebut.

Secara keseluruhan pelaksanaan pemungutan pajak daerah di Kabupaten Bolaang Mongondow telah dilaksanakan sesuai dengan Peraturan Pemerintah No. 55 Tahun 2016. Namun dalam penagihan dan pendataan pajak daerah, Badan Keuangan Daerah dalam hal ini bidang penagihan dan pendataan masih menemui kendala. Kendala yang ditemui dalam hal ini jika dikaitkan dengan implementasi kebijakan, pada prinsipnya adalah cara agar sebuah kebijakan dapat mencapai tujuannya tidak lebih dan kurang. Untuk mengimplementasikan kebijakan publik, maka ada dua pilihan langkah yang ada, yaitu langsung mengimplementasikan dalam bentuk program-program atau melalui formulasi kebijakan derivate atau turunan dari kebijakan tersebut. Kebijakan publik dalam bentuk UndangUndang atau Peraturan Daerah adalah jenis kebijakan yang memerlukan kebijakan publik penjelas atau sering diistilahkan sebagai peraturan pelaksanaan (Dwijowijoto, 2004: 158). 


\section{Kendala Pelaksanaan Pemungutan Pajak Daerah}

Terdapat 4 (empat) faktor yang menjadi kendala pelaksanaan pemungutan pajak daerah di Kabupaten Bolaang Mongondow yaitu 1) sumber daya manusia; 2) anggaran dan fasilitas; 3) kesadaran wajib pajak;

1. Sumber daya manusia menjadi salah satu faktor kendala dalam proses pemungutan pajak, dimana dalam proses pemungutan pajak daerah di Kabupaten Bolaang Mongondow masih terhambat oleh kurangnya jumlah fiskus atau aparatur daerah yang berstatus pegawai negeri sipil yang hanya berjumlah 16 orang di bidang penagihan dan pendataan pajak daerah mengingat lokasi wilayah Bolaang Mongondow yang sangat luas tidak sebanding dengan jumlah fiskus yang ada. Selain kendala pada kuantitas SDM, ditemukan bahwa kualitas SDM juga menjadi kendala dalam proses pemungutan pajak karena masih banyak fiskus yang belum mengikuti pelatihan khusus menjadi fiskus, hanya beberapa saja yang telah mengikuti pelatihan tersebut.

Menurut Hasibuan (2000:3), sumber daya manusia adalah semua manusia yang terlibat di dalam suatu organisasi dalam mengupayakan terwujudnya tujuan organisasi tersebut. Sumber daya manusia merupakan suatu proses untuk menumbuhkan atau meningkatkan suatu potensi fisik dan psikis manusia untuk mencapai tujuan dari suatu organisasi (lembaga) yang dilakukan dengan cara mendaya gunakan manusia sebagai tenaga kerja atau yang melakukan pekerjaan (Sudayat, 2009). Lebih lanjut Sudayat (2009) menyebutkan bahwa sumber daya manusia adalah ujung tombak pelayanan, sangat diandalkan untuk memenuhi standar mutu yang diinginkan oleh wajib pajak dan wajib retribusi. Untuk mencapai standar mutu tersebut, maka harus diciptakan situasi yang mendukung pelayanan yang memuaskan wajib pajak dan wajib retribusi.

Anggaran dan fasilitas menjadi kendala selanjutnya pada pelaksanaan pemungutan pajak daerah. Kurangnya anggaran dan dukungan sarana prasarana yang belum memadai menjadi hambatan bagi fiskus yang harus menjalankan tugasnya untuk melakukan penaginan pajak dan pendataan wajib pajak baru di wilayah Kabupaten Bolaang Mongondow yang cukup luas.

Anggaran sebagai salah satu alat bantu manajemen memegang peranan penting karena dengan anggaran manajemen dapat merencanakan, mengatur dan mengevaluasi jalannya suatu kegiatan. Menurut Nafarin (2012:19), anggaran adalah rencana tertulis mengenai kegiatan suatu organisasi yang dinyataka secara kuantitatif untuk jangka waktu tertentu dan umumnya dinyatakan dalam satuan uang. Sedangkan anggaran menurut National Committee on Governmental Accounting (NCGA) yang dikutip oleh Haruman (2010:6) mengemukakan bahwa anggaran adalah rencana operasi keuangan yang mencakup estimasi pengeluaran yang diusulkan dan sumber pendapatan yang diharapkan untuk membiayainya dalam periode waktu tertentu. Terbatasnya anggaran menyebabkan disposisi para pelaku rendah bahkan akan terjadi goal displacement yang dilakukan oleh pelaku terhadap pencapaian tujuan dan sasaran yang telah ditetapkan (Edward III, 1980).

3. Kesadaran wajib pajak. Kendala yang paling sering ditemui dalam pelaksanaan pemungutan pajak daerah pada umumnya dan terjadi hampir diseluruh daerah yaitu kesadaran wajib pajak. Kendala ini berupa kesadaran wajib pajak yang masih minim seperti melaporkan objek pajaknya kepada pemerintah daerah melalui badan keuangan daerah. Sering kali wajib pajak menunda penyetoran pajak atau mangkir dari petugas yang bertugas menagih pajak langsung ke lapangan. Menurut Harahap (2004:43), kesadaran wajib pajak adalah sikap mengerti wajib pajak badan atau perorangan untuk memahami arti, fungsi dan tujuan pembayaran pajak. Pendapat lain menurut Nasution (2006:7) kesadaran wajib pajak merupakan sikap wajib pajak yang memahami dan mau melaksanakan kewajibannya untuk membayar pajak dan telah melaporkan semua penghasilannya tanpa ada yang disembunyikan sesuai dengan ketentuan yang berlaku.

Indikator kesadaran wajib pajak menurut Muliari (2011) adalah 1) mengetahui adanya undang-undang dan ketentuan perpajakan; 2) mengetahui fungsi pajak untuk pembiayaan negara; 3) memahami bahwa kewajiban perpajakan harus dilaksanakan sesuai dengan ketentuan yang berlaku; 4) memahami fungsi pajak untuk pembiayaan Negara; 5) menghitung, membayar, melaporkan pajak dengan suka rela; 6) menghitung, membayar, melaporkan pajak dengan benar. Kesadaran merupakan unsur dalam diri manusia untuk memahami realitas dan bagaimana mereka bertindak atau bersikap terhadap realitas. Jatmiko (2006) menjelaskan bahwa kesadaran adalah keadaan mengetahui atau mengerti. 
Indikator kesadaran wajib pajak menurut Irianto (2005: 36) adalah sebagai berikut:

1. Kesadaran bahwa pajak merupakan bentuk partisipasi dalam menunjang pembangunan negara. Dengan menyadari hal ini, wajib pajak mau membayar pajak karena merasa tidak dirugikan dari pemungutan pajak yang dilakukan. Pajak disadari digunakan untuk pembangunan negara guna meningkatkan kesejahteraan warga negara.

2. Kesadaran bahwa penundaan pembayaran pajak dan pengurangan beban pajak sangat merugikan negara. Wajib pajak mau membayar pajak karena memahami bahwa penundaan pembayaran pajak dan pengurangan beban pajak berdampak pada kurangnya sumber daya finansial yang dapat mengakibatkan terhambatnya pembangunan negara.

3. Kesadaran bahwa pajak ditetapkan dengan Undang-Undang dan dapat dipaksakan. Wajib pajak akan membayar karena pembayaran pajak disadari memiliki landasan hukum yang kuat dan merupakan kewajiban mutlak setiap warga negara.

Lebih lanjut Irianto (2005) menguraikan beberapa bentuk kesadaran membayar pajak yang mendorong wajib pajak untuk membayar pajak, 1) kesadaran bahwa pajak merupakan bentuk partisipasi dalam menunjang pembangunan negara; 2) kesadaran bahwa penundaan pembayaran pajak dan pengurangan beban pajak sangat merugikan negara; 3) kesadaran bahwa pajak ditetapkan dengan Undang-Undang dan dapat dipaksakan.

\section{Upaya - Upaya Dalam Mengatasi Kendala Pemungutan Pajak Daerah Dalam Peningkatan Penerimaan Asli Daerah}

1. Sumber daya manusia. Upaya yang dilakukan oleh Pemerintah Kabupaten Bolaang Mongondow dalam rangka mengatasi kendala yang ditemui dalam pelaksanaan pemugutan pajak daerah yaitu dalam bentuk perbaikan sumber daya manusia dengan menambah pegawai negeri sipil yang nantinya akan diikutkan dalam pelatihan perpajakan melalui Badan Kepegawaian Daerah dengan mengevaluasi satuan kerja perangkat daerah yang mempunyai pegawai negeri sipil yang lebih guna menutupi kekurangan PNS di Badan Keuangan Daerah. kepemimpinan yang handal dan perlunya sosialisasi guna memberikan wawasan kepada wajib untuk menumbuhkan kesadaran bagi wajib pajak.Selain itu Badan Keuangan Daerah mengupayakan dengan mengadakan sosialiasi dan mengikut sertakan para staf di bidang pendapatan pajak pada kegiatan bimtek atau sebagainya yang dilaksanakan atas kerjasama dengan pemerintah Kota Kotamobagu untuk dibekali dengan pengetahuan dan perkembangan kebijakan-kebijakan terbaru tentang perpajakan yang diharapkan mampu memperbaiki dan meningkatkan kualitas dalam hal kompetensi SDM yang bertugas dalam melaksanakan pemungutan pajak daerah.

Kompetensi merupakan sebuah karakteristik dasar seseorang yang mengindikasikan cara berpikir, bersikap dan bertindak, serta menarik kesimpulan yang dapat dilakukan dan dipertahankan oleh seseorang pada waktu periode tertentu (Moeheriono, 2009:4). Kompetensi menurut Kamus Besar Bahasa Indonesia (2015, versi 1.4) adalah kewenangan (kekuasaan) untuk menentukan (memutuskan sesuatu); kemampuan menguasai gramatika suatu bahasa secara abstrak atau batiniah. Selanjutnya Hutapea dan Thoha (2008:8) mengungkapkan bahwa ada tiga komponen utama pembentukan kompetensi, yaitu: 1) pengetahuan (knowledge) adalah informasi yang dimiliki seorang pegawai untuk melaksanakan tugas dan tanggung jawabnya sesuai bidang yang digelutinya (tertentu). Ilmu atau informasi yang dimiliki seorang pegawai dapat digunakan dalam kondisi nyata dalam suatu pekerjaan. Pengetahuan pegawai turut menentukan berhasil tidaknya pelaksanaan tugas yang dibebankan kepadanya, pegawai yang mempunyai pengetahuan yang cukup meningkatkan efisiensi perusahaan ; 2) keterampilan (skill) merupakan suatu upaya untuk melaksanakan tugas dan tanggungjawab yang diberikan perusahaan kepada seorang pegawai dengan baik dan maksimal, misalnya keterampilan bekerja sama dengan memahami dan memotivasi orang lain, baik secara individu atau kelompok. Keterampilan ini sangat diperlukan bagi pegawai yang sudah menduduki jabatan tertentu, karena keterampilan ini sangat berpengaruh dalam berkomunikasi, memotivasi, dan mendelegasi; 3) sikap (attitude) merupakan pola tingkah seorang pegawai didalam peran melaksanakan tugas dan tanggungjawabnya sesuai dengan peraturan perusahaan. Apabila pegawai mempunyai sifat mendukung pencapaian organisasi, maka secara otomatis segala tugas yang dibebankan kepadanya akan dilaksanakan sebaikbaiknya.

2. Anggaran dan fasilitas. Upaya selanjutnya yang dilakukan oleh Pemerintah Daerah Kabupaten Bolaang Mongondow dalam rangka mengatasi kendala anggaran dan fasilitas yaitu penambahan anggaran, melalui proses penganggaran dalam APBD dan pengalokasian anggaran tersebut untuk 
menunjang aktivitas pemungutan pajak agar dapat terlaksana secara optimal, efektif dan efisien. Selain itu penambahan anggaran operasional guna mengoptimalkan penerimaan pajak daerah dengan menambah mobilitas baik roda empat maupun roda dua guna menunjang petugas dalam melaksanakan tugasnya di lapangan. Upaya lainnya para fiskus menyiasati dengan mengorbankan materi dan bahkan kendaraan mereka untuk menjalankan tugasnya.

Anggaran sebagai salah satu alat bantu manajemen memegang peranan penting karena dengan anggaran manajemen dapat merencanakan, mengatur dan mengevaluasi jalannya suatu kegiatan. Menurut Nafarin (2012:19), anggaran adalah rencana tertulis mengenai kegiatan suatu organisasi yang dinyatakan secara kuantitatif untuk jangka waktu tertentu dan umumnya dinyatakan dalam satuan uang. Terbatasnya anggaran yang tersedia menyebabkan kualitas pelayanan terhadap publik yang harus diberikan kepada masyarakat juga terbatas. Sumber daya berupa fasilitas merupakan sarana yang digunakan untuk operasionalisasi implementasi suatu kebijakan yang akan memudahkan dalam memberikan pelayanan (Edward III, 1980:102). Lebih lanjut Edward III, (1980) menyatakan terbatasnya anggaran menyebabkan disposisi para pelaku rendah bahkan akan terjadi goal displacement yang dilakukan oleh pelaku terhadap pencapaian tujuan dan sasaran yang telah ditetapkan. Terbatasnya fasilitas yang diperlukan dalam pelaksanaan kebijakan menyebabkan gagalnya pelaksanaan kebijakan, karena dengan terbatasnya fasilitas sulit untuk mendapatkan informasi yang akurat, tepat, andal dan dapat dipercaya akan sangat merugikan pencapaian target dalam hal penerimaan pajak daerah.

3.

Kepemimpinan merupakan salah satu upaya yang dilakukan dalam mengatasi kendala kesadaran wajib pajak terutama wajib pajak badan usaha yang sering ditemui kurang patuh membayar pajak daerah di Kabupaten Bolaang Mongondow. Bentuk kepemimpinan ini berupa pemberlakuan sistem reward dan punishment bagi objek pajak seperti mencabut izin perusahaan dan memberikan sanksi administrasi berupa denda kepada wajib pajak yang tidak patuh.

Selain itu sistem reward dan punishment ini juga berlaku bagi petugas pajak (fiskus) yang melaksanakan pemungutan pajak daerah langsung ke lapangan. Penerapan sistem ini yaitu berupa pemberikan insentif kepada petugas pajak yang dinilai dari kinerja pemungut pajak setiap triwulan dari jumlah pendapatan pajak daerah yang dihasilkan dari pelaksanaan pemungutan pajak daerah sampai dengan akhir jatuh tempo pembayaran pajak yang mampu mencapai realisasi hingga $100 \%$. Namun apabila realisasi penerimaan pajak daerah ini tidak terealisasi sesuai target sampai akhir jatuh tempo, maka insentif tidak diberikan kepada petugas pajak tersebut. Hal ini dinilai efektif untuk mencapai realisasi yang diharapkan atas target yang ditetapkan sehingga mampu meningkatkan pendapatan asli daerah.

Teori perilaku atas kepemimpinan lebih terfokus pada tindakan-tindakan yang dilakukan pemimpin dari pada memperhatikan atribut yang melekat pada diri seorang pemimpin. Dasar pemikiran teori ini adalah kepemimpinan merupakan perilaku seseorang ketika melakukan kegiatan pengarahan suatu kelompok kearah pencapaian tujuan. Menurut Fread Fiedler dalam Sutikno (2014:27), kepemimpinan yang berhasil bergantung kepada penerapan gaya kepemimpinan terhadap situasi tertentu. Sehingga suatu gaya kepemimpinan akan efektif apabila gaya kepemimpinan tersebut digunakan dalam situasi yang tepat.

4. Sosialisasi merupakan salah satu cara dan upaya yang dinilai efektif dalam memberikan pemahaman dan pengetahuan tentang pajak daerah baik bagi wajib pajak maupun dalam rangka peningkatan kualitas sumber daya manusia. Sosialisasi untuk pemahaman wajib pajak ini dilakukan baik secara face to face dengan wajib pajak maupun melalui media baik media massa maupun elektronik. Sosialiasi yang dilakukan dengan memberikan pemahaman dan pengetahuan baik kepada masyarakat maupun wajib pajak akan pentingnya pajak dalam memberikan kontribusi bagi pembangunan daerah dan kesejahteraan masyarakat. Hal ini diharapkan mampu memberikan umpan balik dari masyarakat selaku wajib pajak dalam menaati peraturan dan membayar pajak tepat pada waktunya.

Secara khusus sosialisasi dikaitkan dengan teori komunikasi instrumental yang dikemukakan oleh Wiliam I. Gorden yang dikutip oleh Mulyana (2015:4) dimana teori komunikasi instrumental mempunyai beberapa tujuan umum yaitu menginformasikan, mengajar, mendorong, mengubah sikap dan kenyakinan, dan mengubah prilaku atau gerakan tindakan, dan juga menghibur. Bila diringkas, maka kesemua tujuan tersebut dapat disebut membujuk (bersifat persuasif). Komunikasi yang bertujuan memberitahuakan atau menerangkan (to inform) mengandung muatan persuasif dalam arti bahwa pembicara menginginkan pendengar mempercayai bahwa fakta atau informasi yang disampaikan akurat dan layak diketahui. 


\section{Penutup}

Kesimpulan dalam penelitian ini adalah : 1) pelaksanaan pemungutan pajak daerah di Kabupaten Bolaang Mongondow mengacu pada Peraturan Pemerintah No. 55 Tahun 2016 dan Peraturan Daerah Nomor 01 Tahun 2017. Regulasi tersebut sekaligus mengatur tentang proses dalam pemungutan pajak yang terdiri dari 5 (lima) tahapan : a) jenis-jenis pajak dan pengaturan penetapan pajak dalam peraturan daerah, b) pendaftaran wajib pajak dan masa pajak, c) penetapan, pembayaran, pelaporan dan ketetapan pajak, d) penagihan dan penghapusan piutang pajak, e) keberatan dan banding; 2) kendala yang ditemui dalam proses pemungutan pajak daerah di Kabupaten Bolaang Mongondow terdiri dari sumber daya manusia yaitu fiskus atau petugas penagih pajak daerah dan petugas yang melakukan pendataan objek pajak baru yang potensial hanya 16 orang berstatus pegawai negeri sipil, hal ini tidak sebanding dengan luas wilayah yang begitu besar. Selanjutnya masih kurangnya anggaran operasional yang tersedia sangat berpengaruh besar bagi petugas guna mengoptimalkan penerimaan pajak daerah dan fasilitas yang belum memadai serta kesadaran wajib pajak yang masih rendah.

Saran yang dapat diberikan dalam penelitian ini adalah : 1) dalam meningkatkan kepatuhan wajib pajak dapat dilakukan oleh pemerintah Kabupaten Bolaang Mongondow dengan mengadakan sosialisasi kepada masyarakat secara rutin dan lebih giat. Sosialisasi yang dilakukan bisa berupa seminar atau sosialisasi perpajakan yang dapat menambah pengetahuan dan pemahaman diri wajib pajak terhadap peraturan perpajakan dan dapat membantu meningkatkan sikap sadar membayar pajak agar masyarakat mau untuk membayar pajak.; 2) meningkatkan alokasi dana operasional untuk menunjang kelancaran pemungutan pajak daerah dengan cara mengajukan penambahan dana melalui Anggaran Pendapatan dan Belanja Daerah (APBD) sesuai kebutuhan dan tepat sasaran; 3) merenovasi dan menambah sarana/fasilitas operasional untuk memperlancar pungutan pajak daerah sesuai kebutuhan operasional. terutama untuk menjangkau ke daerah yang jauh dan ibukota kabupaten melalui rencana Anggaran Pendapatan dan Belanja Daerah; 4) menambah SDM dalam hal petugas pemungut pajak melalui Badan Kepegawaian Pendidikan dan Pelatihan Daerah Kabupaten Bolaang Mongondow, sesuai kebutuhan untuk selanjutnya perlu pendidikan dan pelatihan khusus mengenai perpajakan daerah. Dengan pendidikan dan pelatihan akan menghasilkan petugas yang lebih handal atau yang kompeten dibidang perpajakan.

\section{Daftar Pustaka}

Amirin, T. M. (2009) Penelitian ekploratori (eksploratif). Yogyakarta.

Dwijowijoto, Riant, Nugroho (2004) Kebijakan Publik, Formulasi Implementasi dan Evaluasi. Jakarta: Gramedia.

Edwards, George C. III (1980) Implementing Public Policy Washington DC: Congressional, Quarterly Press Ekonisia Fakultas Ekonomi UII.

Harahap, Abdul Asri (2004) Paradigma Baru Perpajakan Indonesia. Penerbit BPFE Yogyakarta.

Haruman, Tendi (2010) Penyusunan Anggaran Perusahaan, Graha Ilmu. Yogyakarta.

Hasibuan, Sayuti (2000) Manajemen Sumber Daya Manusia: pendekatan non sekuler.Muhammadiyah University Press and Magister Manager UMS, Surakarta.

Hutapea, Thoha (2008) Kompetensi Plus. Jakarta: PT Gramedia Pustaka Utama.

Ibrahim (2015) Metodologi Penelitian Kualitaif, CV Alfabeta.

Irianto, S. E (2005) Politik Perpajakan: Membangun Demokrasi Negara. Yogyakarta: UII Press.

Jatmiko, Agus (2006) Pengaruh Sikap Wajib Pajak pada Pelaksanaan Sanksi Denda, Pelayanan Fiskus dan Kesadaran Perpajakan Terhadap Kepatuhan Wajib Pajak Studi Empiris Terhadap Wajib Pajak Orang Pribadi di Kota Semarang. Universitas Diponegoro: Tesis Megister Akuntansi.

Kamus Besar Bahasa Indonesia (2015) versi 1.4

Moeheriono (2009) Pengukuran Kinerja Berbasis Kompetensi: Competency Based Human Resource Management. Jakarta: Ghalia Indonesia.

Muliari (2011) Pengaruh Persepsi Tentang Sanksi Perpajakan dan Kesadaran Wajib Pajak Pada Kepatuhan Pelaporan Wajib Pajak Orang Pribadi Di Kantor Pelayanan Pajak Pratama Denpasar Timur. Jurnal Akuntansi dan Bisnis, Volume 2.

Mulyana, Deddy (2015) Ilmu Komunikasi: Suatu Pengantar. Cetakan ke 18. Bandung: PT. Remaja Rosdakarya. 
Nafarin (2012) Penganggaran Rencana Kerja perusahaan. Edisi Kesatu. Jakarta: Salemba Empat.

Nasution (2006) Perpajakan. Jakarta: Bumi Aksara.

Republik Indonesia, Undang-Undang Nomor 28 Tahun 2009 tentang Pajak Daerah dan Retribusi Daerah. Lembaran Negara Republik Indonesia Tahun 2009 Nomor 130.

Republik Indonesia, Undang-Undang Nomor 16 Tahun 2009 tentang Ketentuan umum dan tata cara perpajakan.

Sudayat, Yayat (2009) Makna dalam wacana. Bandung : Irama Widya.

Sugiyono. (2012) Memahami Penelitian Kualitatif'. Bandung: CV Alfabeta.

Sugiyono, (2015) Memahami Penelitian Kualitatif, Bandung: CV. Alfabeta.

Sutikno, Sobry (2014) Metode dan Model-Model Pembelajaran Menjadikan Proses Pembelajaran Lebih Variatif, Aktif, Inovatif, Efektif, dan Menyenangkan. Lombok: Holistica. 